\title{
Yoğun bakım ünitesi ve palyatif bakım servisinde çalışan hekim ve hemşirelerinin iyi ölüme ve saygın ölüm ilkelerine ilişkin tutumları
}

\section{The attitudes of physicians and nurses working in the intensive care unit and palliative care unit towards good death and respectable death principles}

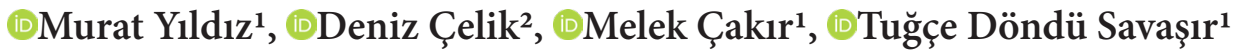 \\ ${ }^{1}$ Sağlık Bilimleri Üniversitesi, Atatürk Göğüs Hastalıkları ve Göğüs Cerrahisi Eğitim ve Araştırma Hastanesi, Göğüs Hastalıkları Yoğun Bakım \\ Ünitesi, Ankara, Türkiye \\ ${ }^{2}$ Alanya Alaaddin Keykubat Üniversitesi, Tip Fakültesi, Göğüs Hastalıkları Anabilim Dalı, Alanya, Antalya, Türkiye
}

Cite this article as/Bu makaleye atıf için: Yıldız M, Çelik D, Çakır M, Savaşır TD. Yoğun bakım ünitesi ve palyatif bakım servisinde çalışan hekim ve hemşirelerinin iyi ölüme ve saygın ölüm ilkelerine ilişkin tutumları. J Med Palliat Care 2021; 2(3): 77-85.

\begin{abstract}
ÖZ
Amaç: Ölümle çok sık karşılaşılan palyatif bakım kliniği ve yoğun bakım kliniklerinde çalışan hemşirelerin ve hekimlerin 'saygın ölüm ilkeleri’ni benimseme düzeylerini ve 'iyi ölüm’e karşı tutumlarını değerlendirme amaçlandı.

Gereç ve Yöntem: Çalışmamız kesitsel olup, hastanemiz göğüs yoğun bakım ünitesi, anestezi yoğun bakım kiniği 1 ve 2, cerrahi yoğun bakım ünitesi ve palyatif bakım servisi 1 ve 2 kliniklerinde çalışan gönüllü 21 hekim ve 109 hemşire bilgi formu, iyi ölüm ölçeği ve saygın ölüm ilkelerine ilişkin tutumları değerlendirme ölçeği doldurarak çalışmaya katıldı.

Bulgular: Çalışmaya dâhil edilen 130 sağlık çalışanlarının \%76,9'u kadındı (n=100). Çalışanların yaşları 20-50 olup yaş ortalaması 30,35 $\pm 7,69$ 'du. Çalışmaya dâhil edilen çalışanların \%16,2'si hekim iken \%83,8'i hemşire/sağlık memuruydu. Saygın ölüm ilkelerine ilişkin tutumları değerlendirme ölçeği için boyutlar için Cronbach alfa katsayısı 0,906 ve İyi ölüm ölçeği için Cronbach alfa 0.921 olarak bulunmuştu. Böylece ölçekteki maddelerin birbiriyle tutarlı ve benzer özelliği değerlendiren maddeler olduğu anlaşıldı. İyi ölüm ve saygın ölüm ilkeleri konularında özel bir eğitim almamış olsalar da çalışmamızdaki hekim ve hemşireler/sağlık memurlarının iyi ölüm ve saygın ölüm ilkelerini benimseme düzeylerinin yüksek olduğu tespit edilmişti. Meslekler arasında anlamlı fark tespit edilmemişti.

Sonuç: Hemşire ve hekimlerin saygın ölüm ilkelerini benimseme düzeylerinin yüksek olduğu izlenen Yoğun bakım ünitesinde ve palyatif bakım servislerinde çalışanlara saygın ölümü ve iyi ölümü yönetmek için gerekli eğitimlerin verilmesi gereklidir.
\end{abstract}

Anahtar Kelimeler: İyi ölüm, saygın ölüm ilkeleri, yoğun bakım, palyatif bakım, hemşirelik

\begin{abstract}
Objective: It was aimed to evaluate the acceptance of "the principles of respectable death" and their attitude towards "the good death" of physicians and nurses working in palliative care services and intensive care clinics, where deaths are common.

Material and Method: Our study is cross-sectional and comprises 21 volunteer physicians and 109 nurses working in the chest intensive care unit, anesthesia intensive care unit 1 and 2, surgical intensive care unit, and palliative care unit 1 and 2 clinics of our hospital. They completed "the good death" scale and "the principles of respectable death" scale.

Results: $23.1 \%$ of the health care workers included in the study were male $(n=30)$ and $76.9 \%$ were female $(n=100)$. The ages of the employees vary between 20 and 50 and the average age is $30.35 \pm 7.69$. While $16.2 \%$ of the employees included in the study are physicians, $83.8 \%$ are nurses/health officers. The Cronbach alpha coefficient for the dimensions of the attitudes towards the principles of respectable death scale was found to be 0.906 and the Cronbach alpha 0.921 for the good death scale. Thus, it was understood that the items in the scale were consistent with each other and evaluating the same feature. Although they did not receive special training on the principles of good death and respectable death, it was found that the physicians and nurses/health officers in our study had a high level of adoption of the principles of good death and respectable death. There is no significant difference between professions in this terms of adoption.

Conclusion: Although the physicians and the nurses have a high level of adoption of the principles of respectable death and the good death, physicians and nurses working in intensive care units and palliative care units must be trained to ensure a respectable death and good death of patients.
\end{abstract}

Keywords: Good death, the principles of respectable death, intensive care, palliative care, nurse 


\section{GíRiş}

Ölüm; tüm canlıların paylaştığı, kaçınılmaz bir durum olup, canlı varlıkların hayati görevlerin geri dönmemek üzere sona erdiği, kişinin maddi ve manevi boyuttaki son evresidir (1).

Ölüme karşı verilen tepkileri içinde yaşanılan toplumda yaşama ve ölüme yüklenen anlamlar, gelenek-görenek, dini yapı, yaş ve gelişmişlik seviyesi ve bireysel değerler etkilemektedir. Ancak tüm dünyada iyi ölüm kavramı önemlidir (1). İyi bir ölüm aynızamanda temel insani bir haktır. Bu sebeple son dönem-ölümcül hastalariçinen önemli beklenti rahat, konforlu, huzurlu ve ağrısız bir şekilde hayatlarının sona ermesidir (2). İyi ölümün öncelikleri; Ölümün ne zaman geldiğini ve ne beklediğimizi anlamayı bilmek, itibar ve mahremiyete saygı̈östermek, ağrının azaltılması ve diğer semptomları kontrol altına almak, ölümü nerede karșılayacağını seçmek, süreçle ilgili bilgiyi edinmek, manevi ihtiyaçları karşılamak, sadece hastanede değil herhangi bir yerde bakımın sağlanması, sonun kiminle paylaşılacağını ve kimlerin olacağının belirlemek, isteklerine saygı duyarak sorunun çözülmesi ve vedalaşmak için zaman ayırmak sayılabilir (3).

Herkes için kaçınılmaz son olan ölümü bilerek yaşayan ve çevresinde ölümle her an karşılaşan insan, ölümü ve sonrasını düşünerek ölüme ilişkin tutumlar geliștirilmiștir. Yaşlı sağlı̆̆ı ve bakımı çalışma grubu tarafından, 1999 yılında "12 saygın ölüm ilkesi” tespit etmiștir. Saygın ölüm ile ilgili, 12 ilkenin sağlık/bakım hizmetlerini sunan sağlık çalışanları tarafından anlaşılması ve bu ilkelere uygun hizmetlerin yürütülmesi tavsiye edilmektedir (4). Saygın ölümü sağlama da hasta ve hasta yakınının ihtiyaçlarının etik ilkelere uygun olarak karşılanması, onurlu ve iyi bir bakımı sağlayabilmek için önemlidir (5). Saygın/ iyi ölümde istenilen amaç kişinin konforunu artırmak, efektif ağrı yönetimi ve gereksiz invaziv girişimlere maruz birakmayarak hastanın duygu-durumunu korumaktır (6). Dünya Sağlık Örgütü tedavinin mümkün olmadığı, yaşam beklentisi olmayan hastaların, iyi ve onurlu bir ölüm hakkı olduğunu belirtmektedir (7).

Kișinin hayatının son döneminde ihtiyaç duyacağı daha insani ve iyi bir sağlık hizmetinin sunulmasında ön saflarda çalıșan özellikle hekim ve hemșirelerin önemi tartıșılmazdır. $\mathrm{Bu}$ çalışmanın amacı ölümle çok sık karşılaşılan palyatif bakım kliniği ve yoğun bakım kliniklerinde çalışan sağlık çalışanlarının saygın ölüm ilkelerini ve iyi ölüm açısından durumlarının tespit etmektir.

\section{GEREÇ VE YÖNTEM}

$\mathrm{Bu}$ çalışma için Sağlık Bilimleri Üniversitesi Ankara Keçiören Eğitim ve Araştırma Hastanesi Baştabipliği Klinik Araştırmalar Etik Kurulu’ndan onay alınmıştır (Tarih: 23.03.2021, Karar No: 2012-KAEK-15/2288).
Çalışmamız kesitsel bir anket çalışması olup, hastanemiz göğüs yoğun bakım kliniği, anestezi yoğun bakım kliniği 1 ve 2, Cerrahi yoğun bakım kliniği ve palyatif bakım kliniği 1 ve 2 kliniklerinde çalışıp ankete katılmak isteyen 21 hekim ve 109 hemşireye, anket soruları cevaplanması için dağıtıllı. Cevaplanan anketler toplanıp, verilerin istatistiksel analizleri yapıldı. Sorulara verilen cevapların doğru ve şeffaf olması çalışmanın objektif olması açısından gerekli önem verildi. Verilen cevaplar başka bir kişi ya da kurumla paylaşılmadı, sadece bu çalışmada veri olarak değerlendirildi. Mevcut çalışmada herhangi bir girişimsel işlem yoktu. Tamamen gönüllülük esasına dayalı bir anket çalışması gerçekleştirildi.

\section{Bilgi Formu}

Yazarlar tarafından hazırlanan bilgi formu ankete katılan sağlık çalışanlarının demografik özelliklerini sorgulayan 13 sorudan ibarettir.

\section{Saygın Ölüm İlkelerine İlişkin Tutumları Değerlendirme Ölçeği (SÖİITDÖ)}

2014 yllında Duyan tarafından geliştirilmiş beşli likert tipte bir ölçektir. SÖİ̇TDÖ'in de, toplam 12 soru bulunmaktadır. Katılımcılardan, sorulara, "Tamamen Katılmıyorum=1", "Katılmıorum=2", "Ne Katıllyorum, $\mathrm{Ne}$ Katılmiyorum=3", "Katıllyorum=4" ve "Tamamen Katıllyorum $=5$ " şeklinde cevap vermesi istenmektedir. Ölçekte yer alan soruların tamamı olumlu ifadelerden oluşmaktadır. Ölçekten alınabilecek en düşük puan 12 iken en düşük puan 60 dır. Ölçekten alınan puan ne kadar yüksek ise, saygın ölüm ilkelerini benimseme düzeyi o kadar yüksektir (7).

\section{İyi Ölüm Ölçeği (İÖÖ)}

Sağlık çalışanlarının iyi ölüm kavramına karşı bakış açılarını belirlemek üzere Schwartz ve ark. (8) tarafından 2003 yılında geliştirilmiştir. Fadıloğlu ve Menekli (9) tarafından 2010 yllında ölçek Türkçe’ye çevrilmiştir. Ölçek 4'lü likert tipli bir olup 17 maddeden oluşmaktadır. Maddeler; hiç (1), biraz (2), orta (3), çok (4) şeklinde değerlendirilmektedir. Ölçek 3 boyuttan oluşmaktadır (kişisel kontrol alt boyut 3 soru toplamıdır, psikososyal manevi alt boyut 9 soru toplamıdır ve klinik alt boyut 5 sorudan oluşmaktadır. İyi ölüm ölçeğinden alınabilecek puan 17-68 arasindadır (9).

\section{İstatistiksel Analiz}

Veriler SPSS 22.0 paket programı ve Windows 10 işletim sistemi ile analiz edildi. Ölçeklerin güvenirliği Cronnbach alfa içtutarlılık katsayısı ile test edilmiştir. Sürekli değişkenlerde dağılım Kolmogorov Smirnov veya Shapiro wilks testleri ile değerlendirildi. Varyansların homojenliğinin değerlendirilmesi için Levene testi kullanıldı. Aksi belirtilmedikçe, sürekli veriler ortalama \pm SD ve kategorik veriler, vaka sayısı (\%) olarak tanımlandı. Normal dağılım gösteren değişkenlerdeki istatistiksel analiz farklılıkları iki bağımsız grup arasında 
Student's t testi ile karşılaştırıldı, normal dağılmayan verilerin karşılaştırmaları için Mann-Whitney $U$ testi uygulandı. İkiden fazla bağımsız grup arasında normal dağılım gösteren değişkenlerdeki farklılıklar One-Way ANOVA ile analiz edilirken, normal olmayan verilerin karşılaştırılmasında Kruskal Wallis testi uygulanmıştır. Tek Yönlü ANOVA veya Kruskal Wallis test istatistiklerinden elde edilen $\mathrm{p}$ değeri istatistiksel olarak anlamlı olduğunda, hangi grubun diğerlerinden farklı olduğunu bilmek için LSD veya Conover'in parametrik olmayan çoklu karşılaştırma testi kullanıldı. Tüm istatistiksel analizlerde $\mathrm{p}<0,05$ değeri anlamlı kabul edildi.

\section{BULGULAR}

Çalışmaya alınan sağlık çalışanlarının \%23,1 (n=30)'i erkek; \%76,9 (n=100)'u kadındı. Çalışanların yaşları 20-

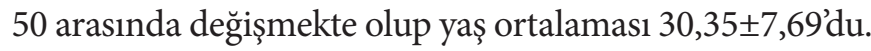
Çalışmaya dâhil edilen çalışanların \%16,2'si hekim iken \%83,8’i hemşire/sağlık memuruydu. Çalışanların \%48,5’i evli, \%51,5'i bekârdı. Çalışanların \%13,1'i ön lisans mezunu, \%66,9'u lisans mezunu ve \%20'si yüksek lisans mezunuydu. Çalışanlar çalışma yılına göre değerlendirildiğinde, \%51,5’i 0-5 y1l, \%18,5’i 6-10 yıl, \%18,5’i 11-15 y1l, \%3,8’i 16-20 yıl ve \%7,7'si 20 yıl üstü süredir çalışmaktaydı. Olguların \%24,6’sı göğüs hastalıkları yoğun bakım, \%42,3'ü anestezi yoğun bakım, \%10'u cerrahi yoğun bakım ve \%23,1'i palyatif bakım servisinde çalışmaktaydı.
Çalışmaya dâhil edilen çalışanların \%89,2'si çalıştığı birimden memnunken, \%47,7'si yaşam sonu hakkında eğitim almış, \%94,6'sı klinikte ölmekte olan hastaya tedavi/bakım vermiş, \%92,3’ü çalıştığı klinikte ölümle karşılaşmıştı. Ayrıca Tablo 1'de anket çalışmasına dahil edilen olguların meslek hayatında ölümle ilk karşılaştıklarındaki hisleri ve aileye ölüm haberi vermek zorunda kalsalar nasıl davranırlardı sorularına verdikleri cevaplar mevcuttu.

Çalışmaya dahil edilen tüm çalışanların SÖİİTDÖ‘den ve İÖÖ ve İÖÖ alt ölçekleri olan psikososyal manevi alt boyut, kişisel kontrol alt boyut ve klinik alt boyut ölçeklerinden aldıkları ortalama puanlar, medyan değerleri ve minimum puan ve maksimum puanlar Tablo 2'de verildi.

\section{Tablo 2. Ölçeklerden alınanı ortalama puanlar, medyan değerler ve} minimum puan ve maksimum puanlar

\begin{tabular}{|lccc|}
\hline n:130 & $\mathbf{X}^{-}$ & \pm SD & (Min-Max) \\
\hline $\begin{array}{l}\text { Saygı́n ölüm İ.İ.T. değerlendirme } \\
\text { ölçi }\end{array}$ & 48,75 & $\pm 7,58$ & $49(31-60)$ \\
İyi ölüm ölçeği & 52,41 & $\pm 9,19$ & $53(28-68)$ \\
Psikososyal manevi alt boyut & 28,55 & $\pm 5,24$ & $29(13-36)$ \\
\multicolumn{1}{|c|}{ Kişisel kontrol alt boyut } & 8,68 & $\pm 2,33$ & $9(3-12)$ \\
\hline \multicolumn{1}{|c|}{ Klinik alt boyut } & 15,18 & $\pm 2,90$ & $15(7-20)$ \\
\hline
\end{tabular}

*Sürekli değişkenler, ortalama \pm standart sapma (SD), (min-max) olarak ifade edildi.

Tablo 1. Katılımcıların ölüme ilişkin deneyimleri ve eğitim alma durumları

Meslek hayatınızda ölümle ilk karşılaștığınızda hissettikleriniz nelerdi?

Aileye ölüm haberini vermek zorunda kalsanız

\begin{tabular}{lcc} 
& n & $(\%)$ \\
Memnun değilim & 14 & $(\% 10,7)$ \\
Memnunum & 116 & $(\% 89,2)$ \\
Almadım & 68 & $(\% 52,3)$ \\
\hline Aldım & 62 & $(\% 47,7)$ \\
\hline Hayır & 7 & $(\% 5,4)$ \\
Evet & 123 & $(\% 94,6)$ \\
Hayır & 10 & $(\% 7,7)$ \\
Evet & 120 & $(\% 92,3)$ \\
Çaresizlik & 17 & $(\% 13,1)$ \\
Başarısızlık & 4 & $(\% 3,1)$ \\
\hline Korku & 7 & $(\% 5,4)$ \\
Üzüntü & 63 & $(\% 48,5)$ \\
Diğer & 20 & $(\% 15,4)$ \\
Çaresizlik, başarısıllık & 1 & $(\% 0,8)$ \\
Çaresizlik, korku & 1 & $(\% 0,8)$ \\
Çaresizlik, üzüntü & 6 & $(\% 4,6)$ \\
\hline Başarısızlık, üzüntü & 1 & $(\% 0,8)$ \\
Korku, üzüntü & 8 & $(\% 6,2)$ \\
Çaresizlik, korku, üzüntü & 2 & $(\% 1,5)$ \\
Normal bir olay kabul eder ve söylerim & 49 & $(\% 37,7)$ \\
\hline Nasıl söyleyeceğime karar vermekte güçlük çekerim & 41 & $(\% 31,5)$ \\
Söylemek istemem & 32 & $(\% 24,6)$ \\
Diğer & 8 & $(\% 6,2)$ \\
\hline
\end{tabular}


Saygın ölüm ilkelerine ilişkin tutumları değerlendirme ölçeği için boyutlar için Cronbach alfa katsayısı 0,906 bulundu. İÖÖ alt ölçekleri olan psikososyal manevi alt boyut için 0,892; kişisel kontrol alt boyut için 0,882 ve klinik alt boyut için 0,757 bulunmuş olup ölçme aracında yer alan maddelerin tamamı değerlendirildiğinde ise İÖÖ için Cronbach alpha 0.921 olarak bulundu. Böylece ölçekteki maddelerin birbiriyle tutarlı ve aynı özelliği değerlendiren maddeler olduğu anlaşıldı.

Çalışmaya dahil edilen tüm çalışanların cinsiyetlerine, yaşlarına, mesleklerine, medeni durumlarına göre SÖİITDÖ'den ve İÖÖ ve İÖÖ alt ölçekleri olan psikososyal manevi alt boyut, kişisel kontrol alt boyut ve klinik alt boyut ölçeklerinden aldıkları puanlar Tablo 3'de karşılaştırıldı. Sonuçlara göre, kadınlarda erkeklere göre saygın ölüm ilkelerini benimseme düzeyi anlamlı düzeyde daha yüksekti $(\mathrm{p}=0,047)$. İyi ölüm ölçeği ve alt ölçekleri açısından cinsiyete göre farklılık bulunmadı (sırasılla $\mathrm{p}=0,459 ; \mathrm{p}=0,784 ; \mathrm{p}=0,175 ; \mathrm{p}=0,940$ ). Yaşı 30 ve üzerinde olanlarda yaşı 30 'un altında olanlara göre klinik alt boyuttan alınan puan anlamlı düzeyde daha yüksekti $(\mathrm{p}=0,003)$. SÖİITTDÖ, İÖÖ ve psikososyal manevi ile kişisel kontrol alt boyut alt ölçekleri açısından yaşa göre farklılık bulunmadı (sirasiyla $\mathrm{p}=0,671 ; \mathrm{p}=0,063 ; \mathrm{p}=0,073$; $\mathrm{p}=0,836$ ). Hemşire/sağlık memurlarında hekimlere göre kişisel kontrol alt boyuttan alınan puan anlamlı düzeyde daha yüksekti $(\mathrm{p}=0,003)$. SÖİITDÖ, İÖÖ ve psikososyal manevi ile klinik alt boyut alt ölçekleri açısından mesleğe göre farklılık bulunmadı (sırasıyla $\mathrm{p}=0,159 ; \mathrm{p}=0,261$; $\mathrm{p}=0,997 ; \mathrm{p}=0,624)$.

\section{Tablo 3. Meslek, yaş, cinsiyet, eğitim alma durumu ve ölüme ilişkin önceki deneyimlere göre ölçeklerden alınan puanların karşılaştırılması}

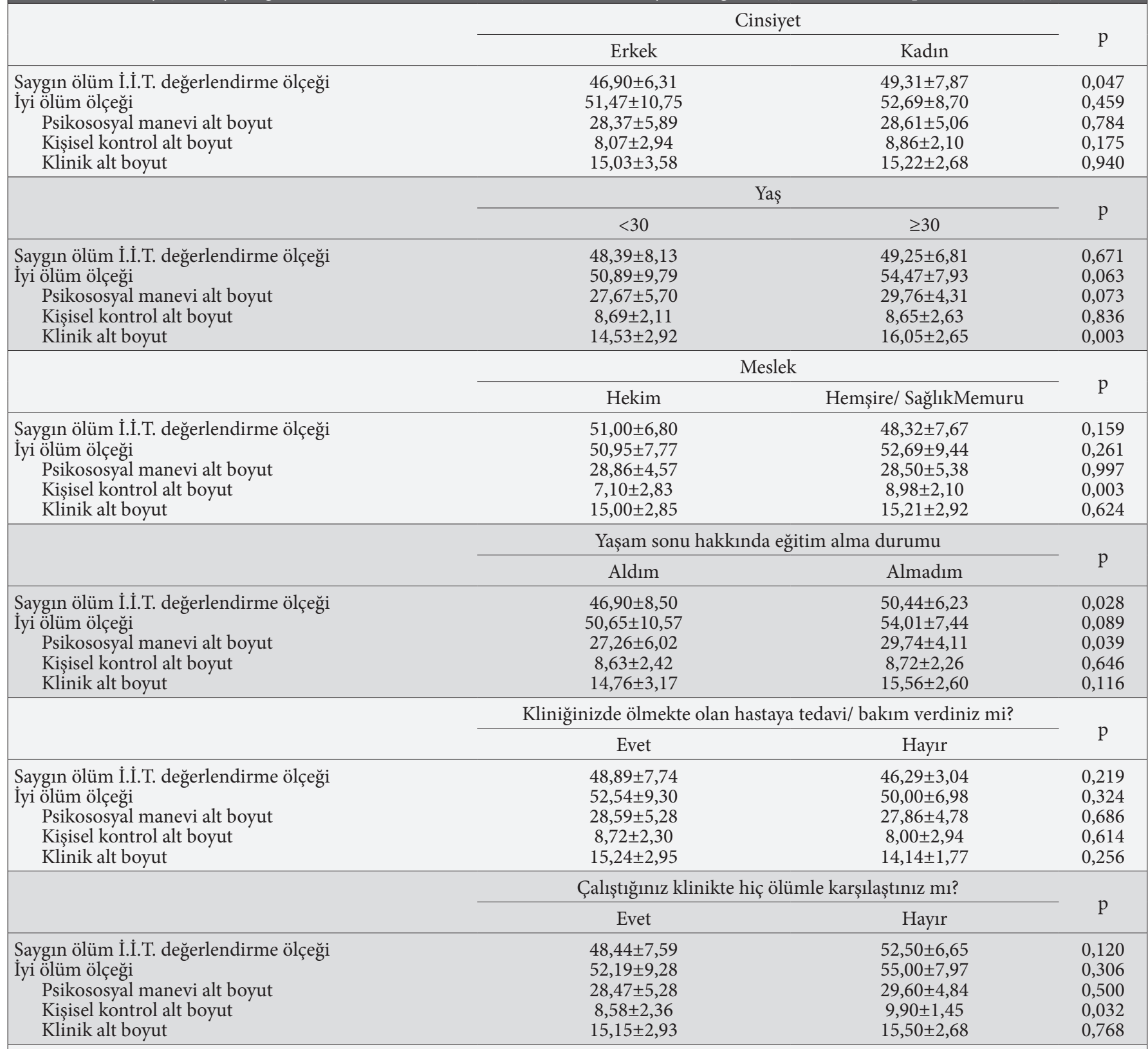

*Sürekli değișkenler ortalama \pm standart sapma (SD) olarak ifade edildi ve sürekli değişsenler student t testi veya Mann-Whitney U testi ile karșılaștırıldı. İstatistiksel olarak anlamlı p değerleri kalın yazılmıştır. 
Çalışmaya dahil edilen tüm çalışanların çalışılan birimden memnuniyet durumuna göre SÖİ̇TDÖ'den ve İÖÖ ve İÖÖ alt ölçekleri olan psikososyal manevi alt boyut, kişisel kontrol alt boyut ve klinik alt boyut ölçeklerinden aldıkları puanlar karşılaştırıldı. Çalışılan birimden memnuniyet durumuna göre SÖİITDÖ, İÖÖ ve alt ölçeklerinden alınan puanlar açısından farklılık bulunmadi.

Çalışanların yaşam sonu hakkında eğitim alma durumuna göre karşılaştırıldığında, eğitim alanlarda almayanlara göre saygın ölüm ilkelerini benimseme düzeyi yapılan istatistik hesaplaması sonuncunda anlamlı olarak daha düşük bulundu $(\mathrm{p}=0,028)$. Eğitim alanlarda almayanlara göre psikososyal manevi alt boyutundan alınan puan anlamlı düzeyde daha düşüktü $(p=0,039)$. İyi ölüm ölçeği ve diğer alt ölçekler açısından yaşam sonu hakkında eğitim alma durumuna göre farklılık bulunmadı (sırasiyla $\mathrm{p}=0,089$; $\mathrm{p}=0,646$; $\mathrm{p}=0,116$ ). Tüm çalışanların saygın klinikte ölmekte olan hastaya tedavi/bakım verme durumuna göre tedavi/bakım verme durumuna göre SÖIIITDÖ, İÖÖ ve alt ölçeklerinden alınan puanlar açısından farklılık bulunmadı (sirasiyla $\mathrm{p}=0,219 ; \mathrm{p}=0,324 ; \mathrm{p}=0,686$; $\mathrm{p}=0,614 ; \mathrm{p}=0,256)$.

Çalışanların çalıştıkları klinikte ölümle karşılaşma durumuna göre karşılaştırıldıklarında, ölümle karşılaşanlarda karşılaşmayanlara göre kişisel kontrol alt boyuttan alınan puan anlamlı düzeyde daha düşüktü $(\mathrm{p}=0,032)$. SÖİITTDÖ, İÖÖ ve psikososyal manevi ile klinik alt boyut alt ölçekleri açısından çalıştıkları klinikte ölümle karşılaşma durumuna göre farklılık bulunmadı (sirasiyla $\mathrm{p}=0,120 ; \mathrm{p}=0,306 ; \mathrm{p}=0,500 ; \mathrm{p}=0,768$ ).
Çalışmaya dahil edilen tüm çalı̧̧anların eğitim durumuna, çalışma yıllarına ve çalışılan kliniğe göre değerlendirildiğinde, saygın ölüm ilkelerine ilişkin tutumları değerlendirme ölçeğinden ve iyi ölüm ölçeği ve iyi ölüm ölçeği alt ölçekleri olan psikososyal manevi alt boyut, kişisel kontrol alt boyut ve klinik alt boyut ölçeklerinden aldıkları puanlar Tablo 4'de karşılaştırıldı. Sonuçlara göre, ön lisans mezunlarının lisans ve yüksek lisans mezunlarına göre saygın ölüm ilkelerini benimseme düzeyi anlamlı düzeyde daha düşüktü $(\mathrm{p}=0,020)$. Yüksek lisans mezunlarının lisans ve ön lisans mezunlarına göre kişisel kontrol alt boyutundan aldıkları puanlar anlamlı düzeyde daha düşüktü $(p=0,044)$. İyi ölüm ölçeği ve diğer alt ölçekler açısından eğitim durumuna göre farklılık bulunmadi (sırasiyla $\mathrm{p}=0,933 ; \mathrm{p}=0,555 ; \mathrm{p}=0,044 ; \mathrm{p}=0,948$ ).

Çalışmaya dahil edilen tüm çalışanların çalışma yılı 0-5 yıl olanların çalışma yılı 11-15 yıl ve 16 yıl ve üstü olanlara göre klinik alt boyutundan aldıkları puanlar anlamlı düzeyde daha düşüktü $(\mathrm{p}=0,026)$. SÖİITTOÖ, İÖÖ ve diğer alt ölçekler açısından eğitim durumuna göre farklilik bulunmadi (sirasiyla $\mathrm{p}=0,981, \mathrm{p}=0,204, \mathrm{p}=0,425$, $\mathrm{p}=0,629)$. Çalışmaya dahil edilen tüm çalışanların çalışılan kliniğe göre anestezi yoğun bakım çalışanlarının palyatif bakım servisi çalışanlarına göre saygın ölüm ilkelerini benimseme düzeyi, psikososyal manevi alt boyut ve klinik alt boyuttan aldıkları puanlar anlamlı düzeyde daha düşüktü (sırasiyla $\mathrm{p}=0,001, \mathrm{p}<0,001$, $\mathrm{p}<0,001)$. Anestezi yoğun bakım çalışanlarının cerrahi yoğun bakım ve palyatif bakım servisi çalışanlarına göre iyi ölüm ölçeği ve kişisel kontrol alt boyutundan aldıkları puanlar anlamlı düzeyde daha düşüktü (sırasıyla $\mathrm{p}=<0,001 ; \mathrm{p}=0,001)$.

Tablo 4. Eğitim durumuna, Çalışma yıllarına ve çalışılan kliniğe göre ölçeklerden alınan puanlar

\begin{tabular}{|c|c|c|c|c|c|c|}
\hline & \multicolumn{4}{|c|}{ Eğitim durumu } & \multirow[b]{2}{*}{$\mathrm{p}$} & \multirow{2}{*}{ Post hoc } \\
\hline & Ön lisans ${ }^{\mathrm{a}}$ & Lisans $^{\mathrm{b}}$ & Yüksek lisans ${ }^{c}$ & & & \\
\hline $\begin{array}{l}\text { Saygın ölüm İ̇.̇.T. değerlendirme ölçeği } \\
\text { İyi ölüm ölçeği } \\
\text { Psikososyal manevi alt boyut } \\
\text { Kişisel kontrol alt boyut } \\
\text { Klinik alt boyut }\end{array}$ & $\begin{array}{c}44,59 \pm 8,18 \\
52,24 \pm 10,38 \\
27,76 \pm 5,49 \\
9,06 \pm 2,44 \\
15,41 \pm 3,00\end{array}$ & $\begin{array}{l}48,86 \pm 7,47 \\
52,52 \pm 9,23 \\
28,46 \pm 5,28 \\
8,97 \pm 2,10 \\
15,09 \pm 2,95\end{array}$ & $\begin{array}{c}51,12 \pm 6,65 \\
52,15 \pm 8,55 \\
29,38 \pm 5,05 \\
7,46 \pm 2,67 \\
15,31 \pm 2,77\end{array}$ & & $\begin{array}{l}0,020 \\
0,933 \\
0,555 \\
0,044 \\
0,948\end{array}$ & $\begin{array}{c}a-b, a-c \\
- \\
- \\
a-c, b-c \\
-\end{array}$ \\
\hline & \multicolumn{4}{|c|}{ Çalışma yılı } & \multirow{2}{*}{$\mathrm{p}$} & \multirow{2}{*}{ Post hoc } \\
\hline & $0-5 \mathrm{yll}^{\mathrm{a}}$ & $6-10 \mathrm{yll}^{\mathrm{b}}$ & $11-15 \mathrm{yll}^{\mathrm{c}}$ & 16 yıl ve üstü ${ }^{\mathrm{d}}$ & & \\
\hline $\begin{array}{l}\text { Saygın ölüm İ.İ.T. değerlendirme ölçeği } \\
\text { Iyi ölüm ölçeği } \\
\text { Psikososyal manevi alt boyut } \\
\text { Kişisel kontrol alt boyut } \\
\text { Klinik alt boyut }\end{array}$ & $\begin{array}{l}48,43 \pm 8,24 \\
51,04 \pm 9,89 \\
27,78 \pm 5,72 \\
8,75 \pm 2,13 \\
14,52 \pm 2,94\end{array}$ & $\begin{array}{l}48,71 \pm 6,48 \\
52,29 \pm 9,95 \\
28,50 \pm 5,46 \\
8,58 \pm 2,50 \\
15,21 \pm 3,09\end{array}$ & $\begin{array}{l}49,17 \pm 6,82 \\
55,58 \pm 5,71 \\
30,25 \pm 3,57 \\
9,17 \pm 1,74 \\
16,17 \pm 2,12\end{array}$ & $\begin{array}{l}49,60 \pm 7,90 \\
53,60 \pm 8,52 \\
29,40 \pm 4,53 \\
7,73 \pm 3,45 \\
16,47 \pm 2,85\end{array}$ & $\begin{array}{l}0,981 \\
0,204 \\
0,425 \\
0,629 \\
0,026\end{array}$ & $\begin{array}{c}- \\
- \\
- \\
- \\
a-c, a-d\end{array}$ \\
\hline \multirow{2}{*}{ Klinik alt boyut } & \multicolumn{4}{|c|}{ Çalışılan klinik } & \multirow[b]{2}{*}{$\mathrm{p}$} & \multirow[b]{2}{*}{ Post hoc } \\
\hline & $\begin{array}{l}\text { Göğüs hastalıkları } \\
\text { yoğun bakım }{ }^{\mathrm{a}}\end{array}$ & $\begin{array}{c}\text { Anestezi } \\
\text { yoğun bakım }\end{array}$ & $\begin{array}{c}\text { Cerrahi } \\
\text { yoğun bakım }\end{array}$ & $\begin{array}{c}\text { Palyatif } \\
\text { bakım servisi }^{\mathrm{d}}\end{array}$ & & \\
\hline $\begin{array}{l}\text { Saygın ölüm İ.İ.T. değerlendirme ölçeği } \\
\text { İyi ölüm ölçeği } \\
\text { Psikososyal manevi alt boyut } \\
\text { Kişisel kontrol alt boyut } \\
\text { Klinik alt boyut }\end{array}$ & $\begin{array}{l}49,66 \pm 7,01 \\
54,38 \pm 6,93 \\
29,75 \pm 3,94 \\
8,97 \pm 2,15 \\
15,66 \pm 2,50\end{array}$ & $\begin{array}{c}45,58 \pm 7,96 \\
48,00 \pm 10,63 \\
26,25 \pm 6,16 \\
7,76 \pm 2,64 \\
13,98 \pm 3,19\end{array}$ & $\begin{array}{l}51,85 \pm 6,83 \\
55,38 \pm 6,81 \\
29,46 \pm 3,57 \\
9,69 \pm 1,75 \\
16,23 \pm 2,71\end{array}$ & $\begin{array}{l}52,27 \pm 5,38 \\
57,10 \pm 5,14 \\
31,10 \pm 3,32 \\
9,60 \pm 1,40 \\
16,40 \pm 1,94\end{array}$ & $\begin{array}{c}0,001 \\
<0,001 \\
0,001 \\
0,001 \\
<0,001\end{array}$ & $\begin{array}{c}\text { b-d } \\
\text { b-c, b-d } \\
\text { b-d } \\
\text { b-c, b-d } \\
\text { b-d }\end{array}$ \\
\hline
\end{tabular}


Çalışmaya dahil edilen tüm çalışanların SÖİITDÖ‘ne verdiklerin cevap dağılımı Tablo 5 te gösterildi. Mesleğe göre farklılıklar değerlendirildiğinde hekimler hemşire/ sağlık memuru grubuna nazaran hastanın ölümün yerini seçebilme ve kontrol edebilme hakkı olduğuna daha kuvvetle inanmakta oldukları görüldü. Diğer sorularda genel yaklaşımlar birbirine benzerdi.

Tablo 5. Tüm çalışanların saygın ölüm ilkelerine ilişkin tutumları değerlendirme ölçeğine verdikleri cevapların dağılımı

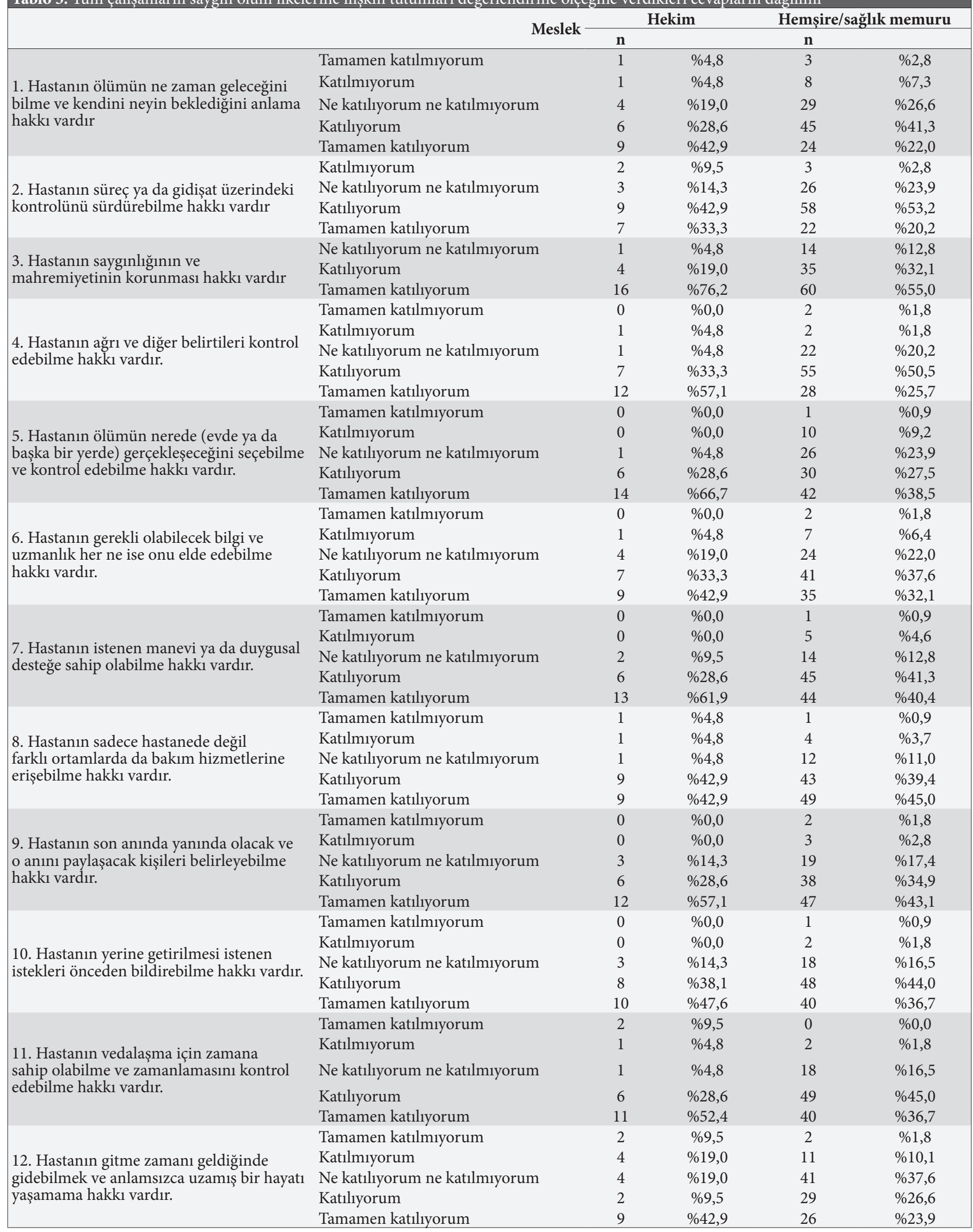




\section{TARTIŞMA}

Araştırmamızda, çalışmaya dahil edilen tüm çalışanların SÖİITDÖ‘den ve İÖÖ ve İÖÖ alt ölçekleri olan psikososyal manevi alt boyut, kişisel kontrol alt boyut ve klinik alt boyut ölçeklerinden aldıkları puan ortalamaları yüksek bulunmuştur. Köse ve ark. (10) yaptığı çalışmada yoğun bakımda çalışan 102 hekim ve hemşirenin SÖİITDÖ'den alınan puan ortalamasını 50,60 $\pm 6,6$ bulmuşlardır. Çelik (11) yoğun bakımda çalıșan 124 hemşire ile yaptığı çalışmada puan ortalaması $43,9 \pm 11,0$ olarak bulunmuştur. Bizim çalışmamızda ise yapılan çalıșmalara benzer olarak puan ortalamasını $48,75 \pm 7,58$ olarak bulduk.

İÖÖ'ni oluşturan maddeler, üç farklı alanı değerlendirmektedir. Üç farklı alt ölçekten herhangi birinde daha yüksek puanlar alınması, İyi Ölüm Kavramının bu alt alanının öneminin arttığını gösterir. Birinci bölüm (Psikososyal ve manevi alt boyut), iyi bir ölümün psikososyal veya ruhsal yönlerini yansitır ve bir ölüm sonrası yaşam deneyimine inanma ile anlamlı sosyal desteğe sahip olma ile, manevi inançlara ve uygulamalara (=ibadet gibi) sahip olma ile ve daha yaşlı olma ve kadın cinsiyet ile ilişkilidir. İkinci bölüm (kişisel kontrol alt boyut), kişisel kontrol ve ölüm deneyiminin daha çok fiziksel yönlerine odaklanır. Ayrıca, daha olumsuz tutum ve ruh hali belirteçleri ile ve ruhsal veya inançlarla bir bağlantıya sahip olmama ile ilişkilidir. Yine, daha genç olma ve bir azınlık grubuna ait olma ile ilişkilidir. Üçüncü bölüm (klinik alt boyut), iyi ölümün klinik ve daha biyomedikal yönlerini gösterir ve ölümün dünyadaki yaşamın olumsuz yönlerinden kurtulma perspektifiyle ve daha yaşlı olma ile ilişkilendirilmiştir (8).

Köse ve arkadaşlarının yoğun bakım kliniklerinde çalışan 102 hekim ve hemşire üzerinde yaptığ 1 çalışmada, cerrahi yoğun bakım kliniğinde çalışan sağlık çalışanların genel yoğun bakım kliniği ve kalp-damar cerrahisi yoğun bakım kliniğinde çalışan sağlık çalışanlarına göre saygın ölüm ilkelerini benimseme durumlarının düşük hesaplanmıştır (10). Çalışmamıza katılanların \%24,6’sı göğüs hastalıkları yoğun bakım, $\% 42,3$ 'ü anestezi yoğun bakım, \%10'u cerrahi yoğun bakım ve $\% 23$,1'i palyatif bakım servisinde çalışmakta idi. Çalışmaya dahil edilen tüm çalışanların çalışlan kliniğe göre anestezi yoğun bakım çalışanlarının palyatif bakım servisi çalışanlarına göre saygın ölüm ilkelerini benimseme düzeyi, İÖÖ psikososyal manevi alt boyut, kişisel kontrol alt boyutundan ve klinik alt boyuttan aldıkları puanlar anlamlı düzeyde daha düşük bulunmuştur. Bu sonuç dahili branş servis ve yoğun bakımında çalışanların cerrahi branş ve yoğun bakım kliniklerine göre tanı ve tedavi süresi boyunca hastalarla daha fazla alakadar olmaları ile açılanabilir.
Bizim çalışmamız literatürle (12) farklı olarak hemşire/ sağlık memurlarında hekimlere göre kişisel kontrol alt boyuttan alınan puan anlamlı düzeyde daha yüksekti. Buna karşın SÖİITDÖ, İÖÖ ve psikososyal manevi ile klinik alt boyut alt ölçekleri açısından mesleğe göre farklılık bulunmamaktaydı. Bu durum hastaneler arası farklı yaklaşımdan veya hekim ve hemşirelerin aldığı eğitimin faklılığından kaynaklanıyor olabileceği düşünüldü.

Hekim ve hemşirelerin iyi ölüme ilişkin algı ve tutumları bir çok farklı faktörden etkilenmektedir. Bunların içinde özellikle yaş, ölüme yaklaşımı etkilemektedir. Birey yaşlandıkça, muhtemel daha çok ölümle karşılaşmış olması nedeniyle ölümü kabullenmesi daha kolay olup, mesleki deneyimin artmasiylada daha pozitif tavırla hastayı yönetebilir. Yaşın yanısıra eğitimde hemşirelerin ölüme yaklaşımını değiştiren bir diğer etmendir. Hemşirelerin eğitim düzeyi ve bilgi ve becerisi yükseldikçe, ölmek üzere olan hastaya yaklaşımları ve tutumları daha iyi, etkin ve olumlu olduğu literatürde belirtilmektedir (13). Bizim çalışmamızda ise kadınlarda erkeklere göre saygın ölüm ilkelerini benimseme düzeyi anlamlı düzeyde daha yüksektir. İÖÖ ve alt ölçekleri açısından cinsiyete göre farklılık bulunmamaktaydı. Yaşı 30 ve üzerinde olanlarda yaşı 30 'un altında olanlara göre klinik alt boyuttan alınan puan anlamlı düzeyde daha yüksek bulduk. SÖİITDÖ, İÖÖ ve psikososyal manevi ile kişisel kontrol alt boyut alt ölçekleri açısından yaşa göre farklılık bulunmamaktaydı. Çalışmaya dahil edilen tüm çalışanlardan çalışma yılı 0-5 yıl olanların, çalışma yılı 11-15 yıl ve 16 yıl ve üstü olanlara göre kişisel kontrol alt boyutundan aldıkları puanlar anlamlı düzeyde daha düşük olduğunu tespit edilmiştir. SÖİITDÖ, İÖÖ ve diğer alt ölçekler açısından eğitim durumuna göre farklılık bulunmamaktaydı. Ayrıca çalışmamızda ön lisans mezunlarının lisans ve yüksek lisans mezunlarına göre saygın ölüm ilkelerini benimseme düzeyi anlamlı düzeyde daha düşüktü. Bu durum literatürle uyumlu olarak yaş,cinsiyet, eğitim durumu değiştikçe vemesleki deneyim arttıkça ölüme karşı tutumun değiştiğini göstermektedir.

Özyalçın’ın yaptığı çalışmada ölmekte olan hastaya bakım veren hemşirelerin \%39,1'i keder-üzüntü, \%34,5'i başarısızlık, \%13,32'ü anksiyete duygularını yaşamakta olduklarını belirtmişlerdir (14). Bizim çalışmamızda ise 'Meslek hayatınızda ölümle ilk karşılaştığınızda hissettikleriniz nelerdi?' sorusuna çalışmaya katılan hekim ve hemşirelerin $\% 48,5$ 'i üzüntü, $\% 13,1^{\prime}$ i çaresizlik, \%6,2'si korku-üzüntü, \%5,4 ü korku şeklinde cevaplamışlardır. Literatürde terminal dönem hastalıkta yada yaşamın son evresinde hekim ve hemşirelerin sıklıkla üzüntü, başarısızlık, çaresizlik, korku, anksiyete gibi duygular yaşadıkları belirtilmektedir $(15,16)$. 
Bizim çalışmamızda da literatürle (12) benzer olarak hekim grubunda saygin ölüm ilkelerinden mahremiyet, ölümün yerini seçme, manevi destek ile ilgili ilkelere en çok katılım olurken hemşire grubunda bu sayılan ilkelere ek olarak hastane dişında da hizmet almak ilkesine yüksek oranda katılmışlardır. Bu da hekim ve hemşirelerin saygın ölüm ilkelerine karşı tutumlarının birbirinden farklı olmadığını göstermektedir.

\section{Çalışmanın Kısıtlılıkları}

Çalışmanın kısıtlılıkları nispeten az sayıda katılımcı ile yapılmış olmasıdır. Bununla birlikte kliniklerde çalışan katılımcı sayılarının birbirinden farklı olması, hekim ve hemşire sayıları arasındaki katılımcı farkının fazla olması ve kliniklerde yeni göreve başlayan, mesleki deneyimi daha az hemşirelerin olması diğer kısıtlılıklardır.

\section{SONUÇ}

Çalışmamızın bulguları değerlendirildiğinde özetle kadınlarda erkeklere göre, 30 yaş üstündekilerde 30 yaş altındakilere göre, yüksek lisans ve lisans mezunlarının ön lisans mezunlarına göre saygın ölüm ilkelerini benimsemeleri düzeylerinin daha yüksek bulundu.

Çalışmaya dahil edilen tüm çalışanların çalışılan kliniğe göre değerlendirildiğinde, anestezi yoğun bakım çalışanlarının palyatif bakım servisi çalışanlarına göre saygın ölüm ilkelerini benimseme düzeyi, İÖÖ psikososyal manevi alt boyut, kişisel kontrol alt boyutundan ve klinik alt boyuttan aldıkları puanlar anlamlı düzeyde daha düşük bulundu.

Çalışanların yaşam sonu hakkında eğitim alma durumuna göre karşılaştırıldığında, eğitim alanlarda almayanlara göre saygın ölüm ilkelerini benimseme düzeyi yapılan istatistik hesaplaması sonuncunda anlamlı olarak daha düşük bulunmuştur $(\mathrm{p}=0,028)$. Eğitim alanlarda almayanlara göre saygın ölüm ilkelerini benimseme düzeyinin daha düşük çıkması alınan eğitimin nitelik, nicelik ve kazanımları açısından değerlendirilmesi gerektiğini, belirli aralıklarla da eğitimlerin tekrar edilmesi gerektiğini düşündürmektedir.

Hekim ve hemşirelerin demografik ve kişisel özellikleri, ölüme ilişkin önceki tecrübeleri, eğitim durumları ve mesleki deneyimleri ölmekte olan hastaların bakımına yönelik tutumlarını değiştirebilir ve şekillendirebilir. Hekim ve hemşirelerin saygın ölüm ilkelerini benimseme düzeylerinin yüksek olduğu yoğun bakım ünitesinde ve palyatif bakım servislerinde görev yapmakta olan sağlık çalışanlarının saygın ölümü ve iyi ölümü sağlamada ihtiyaç duydukları eğitimin sağlanması önemlidir. Hemşireler, hekimlere göre son dönemini yaşayan hastalar ile daha fazla vakit geçirmektedirler. Ölmek üzere olan hastalara bakım ve ölüm olgusunun ele alınması, hekimlik ve hemşirelik mesleğinin belki de en zor tarafıdır.
Özellikle hemşirelerin ölmekte olan hastaya hizmet verme deneyimi ve iyi ölüm kavramına ve saygın ölüm ilkelerine ilişkin yaklaşımı hasta bakımının kalitesi üzerinde oldukça önemlidir. İyi ölümün sağlanmasında gerekli sağlık bakım stratejilerin planlanması ve geliştirilmesi için hekimlerin ve hemşirelerin iyi ölüme yönelik olumlu ve olumsuz algılarını belirleyecek güvenli ve geçerli ölçekleri kullanmak gereklidir.

\section{ETİK BEYANLAR}

Etik Kurul Onayı: Bu çalışma için Sağlık Bilimleri Üniversitesi Ankara Keçiören Eğitim ve Araştırma Hastanesi Baştabipliği Klinik Araştırmalar Etik Kurulu'ndan onay alınmıştır (Tarih: 23.03.2021, Karar No: 2012-KAEK-15/2288).

Aydınlatılmış Onam: Çalışma kesitesel anket çalışması olarak dizayn edildiği için katılımcılardan aydınlatılmış onam alınmıştır.

Hakem Değerlendirme Süreci: Harici çift kör hakem değerlendirmesi.

Çıkar Çatışması Durumu: Yazarlar bu çalışmada herhangi bir çıkara dayalı ilişki olmadığını beyan etmişlerdir.

Finansal Destek: Yazarlar bu çalışmada finansal destek almadıklarını beyan etmişlerdir.

Yazar Katkıları: Yazarların tümü; makalenin tasarımına, yürütülmesine, analizine katıldığını ve son sürümünü onayladıklarını beyan etmişlerdir.

\section{KAYNAKLAR}

1. Peykerli G. Ölümcül hastalıklara psikolojik yaklaşım. Cumhuriyet Üniversitesi Tip Fakültesi Derg 2003; 25: 62-65.

2. Van der Geest S. Dyingpeacefully: Considering good death and bad death in Kwahu-Tafo, Ghana. Soc Sci Med 2004; 58: 899-11.

3. Yao CA, Hu WY, Lai YF, Cheng SY, Chen CY, Chiu TY. Does dying at home influence the good death of terminal cancer patients? J Pain Symptom Manage 2007; 2: 3-6.

4. Debate of the age. The Millenium Papers, The Future of Health and Care of Older People: The Best is Yetto Come, Age Concern Published, London, England 1999; 41-46.

5. Beuks B, Nijhof AC, Meertens JH, Ligtenberg J, Tulleken J, Zijistra J. A good death. Intensive Care Med 2006; 32: 752-3.

6. Wasserman LS. Respectfuldeath: a model for end-of-life care. Clin J Oncol Nurs 2008; 12: 621-6.

7. Duyan V. Saygın ölüm ilkelerine ilișkin tutumları değerlendirme ölçeği'nin geçerlik ve güvenirlik çalışması. Turk J Fam Med Primary Care 2014; 8: 25-31.

8. Schwartz CE, Mazor K, Rogers J, Yunsheng MA, Reed G. Validation of a new measure of concept of a good death. J Palliat Med 2003; 6: 4-7.

9. Fadıloğlu Ç, Aksu T. İyi ölüm ölçeğinin geçerlilik ve güvenirliği Ege Üniversitesi Hemşirelik Fakültesi Derg 2013; 29: 1-15.

10. Köse S, İnal Tunalı B , Yıldırım G. Yoğun bakımda çalışan hekim ve hemşirelerin ölüm ve saygın ölüm ilkelerine ilişkin tutumları. YBHD 2019; 23: 9-17. 
11.Çelik N. Yoğun bakım hemşirelerinin ölüme ve saygın ölüm ilkelerine ilişkin tutumları. Mersin Univ Saglık Bilim Derg 2019; 12: 316-27.

12. Dağ A, Badır A. Hekim ve hemşirelerin bazı özelliklerinin saygın ölüm ilkelerine ilişkin tutumlar üzerine etkisi. DEUHFED 2017; 10: 186-92.

13.Iranmanesh S, Dargahi H, Abbaszadeh A. Attitudes of Iranian nurses toward caring for dying patients. Palliat Support Care 2008; 6: 363-9.

14.Dilan Ö. Kanser hastaları, yakınları ve hemșirelerin ölüme ve iyi ölüme ilişkin görüşleri. Başkent Üniversitesi Sağlık Bilimleri Enstitüsü Hemşirelik Tezli Yüksek Lisans Programı 2019.

15.Koku F, Ateș M. Terminal dönem hasta bakımının niteliğini geliştirmede hemşirelerin ölüme ilişkin deneyim ve tutumları. Sağlık ve Hemşirelik Yönetimi Derg 2016; 3: 99-104.

16. Sahin M, Demirkıran F, Adnan F. Pursing students death anxiety, influencing factors and request of caring for dying people. J Psychiatr Nurs 2016; 7: 135-41. 